\title{
THE PRELIMINARY EXAMINATION IN THE FEDERAL SYSTEM: A PROPOSAL FOR A RULE CHANGE
}

\section{INTRODUCTION}

Although the purpose of the preliminary hearing seems to be confined to avoidance of unreasonable pretrial detention, its function is somewhat broader. In practice, the preliminary hearing may serve as a valuable device to discover the prosecution's case, particularly in the absence of other effective means of discovery. This explains why the prosecutor ordinarily seeks to avoid such hearings. ${ }^{1}$

In the federal system, the United States Attorney frequently bypasses the preliminary hearing ${ }^{2}$ by asking the commissioner for a continuance in order to gain time to go to the grand jury for an indictment. Once an indictment has been returned, most courts hold that the necessity for a preliminary hearing has been mooted. ${ }^{3}$ This Comment will seek to demonstrate the undesirable consequences which flow from such a prosecutorial strategy. Through an analysis of the development and functions of the preliminary examination, it will be seen that this examination is a device which continues to have an important, if limited, role to play in the administration of criminal justice. Under the present Federal Rules of Criminal Procedure, however, the standard mootness holding cannot be avoided. Therefore, a revision of the rules will be proposed to ensure that an examination will be held.

\section{Development and Functions of the Preliminary Examination}

The preliminary examination emerged in England in the midsixteenth century, ${ }^{4}$ apparently adopted to get some degree of govern-

18 J. MoORe, Federal PRACTICe $\int 5.04$ [1], at 5-28 (2d ed. 1967).

2 The terms "preliminary examination" and "preliminary hearing" are used interchangeably throughout this Comment.

${ }^{3}$ See note 29 infra. The cases are unanimous in holding that there is no constitutional right to a preliminary examination. United States ex rel. Hughes v. Gault, 271 U.S. 142 (1926) (Holmes, J.) ; Goldsby v. United States, 160 U.S. 70 (1895); Dillard v. Bomar, 342 F.2d 789 (6th Cir.), cert. denied, 382 U.S. 883 (1965) ; Garrison v. Johnston, 104 F.2d 128 (9th Cir.), cert. denied, 325 U.S. 887 (1945); Wood v. Ünited States, 128 F.2d 265 (D.C. Cir. 1942) (dictum) (Rutledge, J.); Clarke v. Huff, 119 F.2d 204 (D.C. Cir. 1941); In re Bates, 2 F. Cas. 1015 (No. 1099a) (D.C. S.C. 1858). But cf. United States ex rel. Hughes v. Gault, 271 U.S. 142, 152 (1926) (separate opinion), where Mr. Justice Brandeis stated that when the commissioner does not hear evidence bearing upon the existence of probable cause, the defendant is deprived of due process of law in violation of the fifth amendment.

4 An Act Touching Bailment of Persons, 1 \& 2 Phil. \& M., c. 13, §4 (1554) ("And that the said justices... when any such prisoner is brought before them for manslaughter or felony, before any bailment ...., shall take the examination of the said 
mental participation in criminal prosecutions. ${ }^{5}$ Justices of the peace (unpaid magistrates) "took evidence virtually as State prosecutors preparing the case for the prosecution ;" examined as to all the circumstances of the alleged offense, while the witnesses for the prosecution were questioned out of the defendant's presence, "their evidence being viewed as only for the information of the court." 7 As late as 1823, grand juries were told that the magistrate, when conducting the preliminary examination, acts inquisitorially, not judicially, that the proceedings are secret, and that the information obtained is given only to the prosecutor and not to the defendant. $^{8}$ The examination began to change significantly, however, when a regular police force was established in the nineteenth century. ${ }^{9}$ With a police force to gather evidence for prosecution, it became easier for the magistrate to act solely as a judge. ${ }^{10}$ These changes were recognized in 1836 by passage of the Prisoner's Counsel Act, which permitted the defendant to inspect all depositions taken against him, ${ }^{11}$ and in 1848 by passage of the Indictable Offenses Act, which provided in indictable cases that prosecution witnesses be examined in the defendant's presence, that the defendant either could "answer to the Charge" or remain silent, and that he could examine witnesses. ${ }^{12}$

By this time, the purpose of the examination in England had become to determine "whether a man should be made to stand his trial." 13 The examination continued to develop, however, and "[a]s so often happens with English legal institutions, the real purpose which the hearing before the magistrates fulfills is not now the one for which it was primarily designed." ${ }^{14}$ In England today the prosecutor must disclose at the preliminary examination all the evidence he intends to present at trial, each witness's testimony being recorded in a signed deposition. ${ }^{15}$ If the prosecutor comes upon any new

prisoner, ... of the fact and circumstances thereof, ... or as much thereof as shall be material to prove the felony shall put in writing before they make the same bailment..."); An Act to Take Examination of Prisoners Suspected of any Manslaughter or Felony, 2 \& 3 Phil. \& M., c. 10 (1555) (extends act of 1554 to those suspected of manslaughter or felony, but who are not bailed).

- 5 See E. Puttkamimer, Administration of Crminal Law 91 (1953).

6 Williams, Introductory Survey of the Preliminary Examination in England, Preliminary Investigation by Magistrates in Great Britain and Canada, in Hearings on $S .3475$ and $S .945$ Before the Subcomm. on Improvements in Judicial Machinery of the Senate Comm. on the Judiciary, 89th Cong., 2d Sess., 90th Cong., 1st Sess. 307 (1967) [These hearings are hereinafter cited as Hearings].

7 L. Orfield, Criminal Procedure From Arrest To Appeal 55 (1947).

8 Id.

Id. at 56.

${ }^{10}$ See id.

$116 \& 7$ Will. 4, c. $114, \S 3(1836)$.

1211 \& 12 Vict., c. $42, \S \S 17-18$ (1848).

13 P. Devlin, The Criminal Prosecution in Engrand 107 (1958).

14 Id. at 111 .

15 Louisell, Criminal Discovery: Dilemma Real or Apparent?, 49 CALIF. L. REv. 56,65 (1961); see note 16 infra. 
evidence after the preliminary examination, he must serve notice on the defense, setting out in the form of a statement by the witness the additional evidence he proposes to use. ${ }^{16}$

In the United States, however, the discovery function of the preliminary examination has not developed to such an extent. In the federal system, the United States Attorney must bring forward only enough evidence to satisfy the commissioner that there is "probable cause to believe that an offense has been committed and that the defendant committed it." 17 Thus the degree of discovery obtained in a preliminary examination will depend, in part, upon how much evidence the magistrate deems necessary to establish probable cause in a particular case. Even a high standard of probable cause will not necessarily disclose all the evidence within the possession of the government that the defendant may need. ${ }^{18}$

Nevertheless, it is very likely that the defendant will discover something, regardless of the quantum of evidence the commissioner thinks sufficient. The United States Attorney must put some witnesses on the stand, and thus defense counsel wiil learn their names and have their testimony recorded, enabling him to impeach them if discrepancies occur at trial. 19 In civil litigation, testimony can be fixed at an early stage by depositions; in criminal litigation, the preliminary examination is the only available counterpart. ${ }^{20}$ Defense counsel's opportunity for pre-trial cross-examination ${ }^{21}$ may also be valuable, since it is difficult at trial to develop inconsistencies in testimony never heard before. ${ }^{22}$ Defense counsel may also be able to learn what written statements, which can be subpoenaed later under the Jencks Act, ${ }^{23}$ have been made by or to the police.

16 P. DevliN, supra note 13, at 112. Lord Devlin notes that when looking for the most convenient authority to cite for this obvious proposition, "to my surprise I found that there was no case in which such a rule had specifically been laid down." Nevertheless, he states "[ $t]$ here is no doubt about the practice...." Id. at 113.

17 FED. R. CRIM. P. 5 (c).

18 See S. REP. No. 371, 90th Cong., 1st Sess. 34 (1967).

19 Statement of Lawrence Speiser, Director, Washington Office, American Civil Liberties Union, Hearings, supra note 6 , at 165.

20 Statement of Roland S. Homet, Attorney, Wash., D.C., Hearings, supra note 6, at 191. FED. R. CRIM. P. 15(a) provides for the taking of depositions, but only from prospective witnesses who "may be unable to attend or prevented from attending a trial" and whose testimony is "material" and must be taken "in order to prevent a failure of justice."

21 FED. R. CRIM. P. 5(c) provides that " $[t]$ he defendant may cross-examine witnesses against him ....."

22 Speiser, Hearings, supra note 19, at 165.

23 Homet, Hearings, supra note 20, at 191. The Jencks Act, 18 U.S.C. $\$ 3500$ (1964), provides for discovery, after a witness has testified on direct examination at trial, of his statements or depositions in government possession.

The discovery advantages set forth in the text accompanying notes 19-24 throw into question one criticism of the usefulness of the preliminary examination as a discovery device: "Discovery. . . . can most usefully take place at a later stage, much closer to trial, when the evidence is more nearly complete and defense counsel is better prepared." S. REP. No. 371, supra note 18, at $34-35$. 
In addition, the information obtained at a preliminary hearing may provide a basis for avoiding trial altogether, ${ }^{24}$ a contingency which benefits the prosecution, the public and the defense. The prosecutor gets an important and useful trial run of some of his essential witnesses and may find that his case is not as strong as he had supposed. Weaknesses do not come out as readily in ex parte grand jury proceedings, where probable cause is determined in secret by laymen under the guidance of the prosecutor and without the benefit of cross-examination or presentation of evidence by defense counsel. ${ }^{25}$ Exposure of a weak case may make the prosecutor more willing to bargain for a guilty plea. On the other hand, the defendant will be able to make a more informed plea since evidence brought out at preliminary examination may enable defense counsel to better gauge the strength of the prosecution's case. ${ }^{26}$ Furthermore, defense counsel may inquire, at least superficially, into the circumstances of arrest, search or confession and thus be better prepared for a motion to suppress ${ }^{27}$ which, if successful, may avoid the expense of a trial.

Historically, then, a device originally intended as a prosecutorial inquiry into the circumstances of a crime has evolved over the course of centuries into one which is primarily of benefit to the defendant by protecting him from unnecessarily lengthy incarceration on unfounded charges and granting him some measure of discovery of the government's case. Even though the former protection may prove superfluous in areas where a grand jury sits frequently, ${ }^{28}$ the latter is important to all defendants in a criminal system with only a minimal number of formal discovery devices.

24 Statement of Samuel Dash, Professor of Law and Director, Institute of Criminal Law and Procedure, Georgetown University Law Center, Hearings, supra note 6, at 141: "Experienced defense counsel and prosecutors who have worked with such a system of preliminary examinations will testify that it is an excellent vehicle for weeding out cases that should go no farther...."

25 See United States v. Wingert, 55 F.2d 960, 961 (E.D.Pa. 1932) (grand jury "no more than a star chamber proceeding with a carefully prepared prima facie case submitted with all suggestions of what may be behind it shut out") (dictum), rev'd sib nom. Ex parte United States, 287 U.S. 241 (1932) ; United States v. Kilpatrick, 16 F. 765, 771 (W.D.N.C. 1883) (noting that Mr. Justice Field felt that preliminary examinations afford "the citizen the greatest security against false accusations from any quarter"); Dash, Hearings, siepra note 24 , at 139 . Contra, L. ORFIELD, sipra note 7 , at 75 ("Magistrates and justices of the peace are frequently scattered throughout the county and ignorant of the law as compared to the prosecutor. Hence they are more likely to be dominated and overridden by the prosecutor than they are to exercise an effective checking influence. A better check than a weak preliminary examination is the grand jury.").

28 "[The preliminary examination] encourages many pleas of guilty at a very early stage, since defense counsel can realistically appraise the case for his client who has been present and confronted by what the prosecutor has to offer against him." Dash, Hearings, supra note 24, at 142 .

27 Homet, Hearings, supra note 20, at 191.

28 It is noted in Memorandum Prepared By Staff of Subcomm. on Improvements in Judicial Machinery, in Hearings, supra note 6 , at 14 , that because the "modern practice" in urban areas is to have the grand jury sit continuously the preliminary examination is "rendered obsolete." But see note 25 suspra. 


\section{Mootness ANd Rule 5(c)}

This Comment is concerned with holdings that a grand jury indictment moots the necessity for a preliminary examination. ${ }^{29}$ Such holdings have been the "basis for generally followed prosecutive strategy of delaying the preliminary hearing until an indictment can be obtained." ${ }^{30}$ But rule 5(c) of the Federal Rules of Criminal Procedure, which governs the preliminary examination in the federal system, speaks to the commissioner in apparently mandatory terms: "If the defendant does not waive the examination, the commissioner shall hear the evidence within a reasonable time." 31 (Emphasis added.)

29 Such holdings are found in cases decided both before and after the adoption of the Federal Rules. Before, e.g.: Van Dam v. United States, 23 F.2d 235 (6th Cir. 1928) ; United States v. Averett, 26 F.2d 676 (W.D.Va. 1928) (citing cases); United States v. Acken, 267 F. 595 (E.D.N.Y. 1920); see Barber v. United States, 142 F.2d 805 (4th Cir.) (unclear whether defendant arrested before indictment), cert. denied, 322 U.S. 741 (1944); United States ex rel. Perry v. Hiatt, 33 F. Supp. 1022 (M.D.Pa. 1940) (same); United States v. Reilly, 30 F.2d 866 (E.D.Pa. 1929) (same). After, e.g.: United States v. Chase, 372 F.2d 453 (4th Cir. 1967); United States v. Heap, 345 F.2d 170 (2d Cir. 1965); Vincent v. United States, 337 F.2d 891 (8th Cir. 1964); James v. Lawrence, 176 F.2d 18 (D.C. Cir. 1949) ; United States v. Elksnis, 259 F. Supp. 236 (S.D.N.Y. 1966); Jones v. United States, 223 F. Supp. 454 (E.D.Mo. 1963), appeal dismissed, 326 F.2d 410 (8th Cir. 1964); United States v. Brace, 192 F. Supp. 714 (D.Md. 1961); Boone v. United States, 185 F. Supp. 411 (W.D.Ky. 1959), aff'd per curiam, 280 F.2d 911 (6th Cir. 1960); United States v. Slaugenhoupt, 102 F. Supp. 820 (W.D.Pa. 1952).

In Jaben v. United States, 381 U.S. 214, 220 (1965), there is dictum to the effect that the defendant must be afforded preliminary examination as required by Rule 5 (c), "unless before the preliminary hearing is held, the grand jury supersedes the complaint procedure by returning an indictment."

80 \& J. Moore, Federai Practice If 5.04[3], at 5-30 (2d ed. 1967). Statements deploring this strategy are fairly common, even in cases following the standard mootness holding. E.g., United States v. Delman, 253 F. Supp. 383 (S.D.N.Y. 1966) (situation deplorable; motion to dismiss indictment denied) ; United States v. Cowan, 37 F.R.D. 215, 217 (S.D.N.Y. 1965) (practice "should not be countenanced"; motion to dismiss indictment denied) ; United States v. Universita, 192 F. Supp. 154, 156 (S.D.N.Y. 1961) ("no apparent reason for delay"; petition for writ of habeas corpus denied).

It seems evident that preliminary examinations are not held very frequently in the federal system. Judge Weinfeld states that "Rule $5 \mathrm{c} .$. . has fallen into disuse, at least in the Southern District of New York. I am unaware of any instance in the last several years in which a defendant has been accorded a hearing." Judicial Conference of the Second Judicial Circuit of the United States, The Problem of Long Criminal Trials, 34 F.R.D. 155, 165 (1963). Much instructive data is found in Staff of Subcomm. on Improvements in Judicial Machinery, Report on United States Commissioner Responses to Subcomm. Questionnaire, Hearings, supra note 6 , at 453 [hereinafter cited as Commissioners Survey]. This questionnaire was mailed to all commissioners and had a return rate of over fifty per cent. It was found that the "pattern of holding a Rule 5(c) preliminary examination in only a small fraction of cases seemed prevalent throughout the responses regardless of the fees earned by the commissioner." Id. at 478. "A commissioner of seven years' service reports that he has never held or scheduled a preliminary hearing and another states: 'In 12 years I never had a preliminary hearing." "Id. at 479. Among the busier commissioners, the reason most frequently given for not holding the preliminary examination was intervening grand jury indictment; the next most frequently given reason was waiver of the examination. Among the commissioners earning less than $\$ 5,001$ these two reasons (again the most frequent) were cited an equal number of times. Id. at 481 . In differentiating the responses by the population of the area where the commissioner sits, the survey indicated that as the population increased, an intervening indictment was more frequently given as a reason for not holding the examination. Id. at 483 .

31 It appears that hearings are sometimes held despite an intervening indictment. In the Commissioners Survey, supra note 30 , at 483, it is reported that "[s] urprisingly, 
The bases for the seemingly unwarranted conclusion that the preliminary examination need not be conducted are found both in the judicial interpretation of the purpose of the preliminary examination and in the Federal Rules themselves. The purpose of the examination is conceived as only "to prevent a person from being held in custody without a prompt hearing." 32 But a grand jury can perform the same function: implicit in the indictment is that there is probable cause to hold the defendant. ${ }^{33}$ Thus, a quick determination of probable cause by the grand jury gives the defendant a prompt hearing and indicates that he is properly being held. Furthermore, the rules themselves lend weight to this argument. A defendant who is arrested on a warrant or summons issued upon an indictment or information is not entitled to a preliminary examination. ${ }^{34}$ Rules 9 (b) (1) and (2), which govern the disposition of such defendants, state that the defendant is to be "brought before the court," rather than before the commissioner, the latter being the route for defendants arrested under a warrant or summons issued upon a complaint ${ }^{35}$ or arrested without a warrant. ${ }^{36}$ To give a post-indictment hearing to a defendant merely because he was arrested before action was instituted by the grand jury would not only be going through a meaningless gesture in terms of probable cause, ${ }^{37}$ but would also be giving a defendant indicted after apprehension an opportunity for discovery not available to those arrested after indictment. ${ }^{38}$ That such a distinction seems arbitrary lends support to the conclusions that the purpose of a preliminary examination is a swift determination of

$9 \%$ of the commissioners answered that they do hold a hearing in such circumstances." Some of these responses might be due to confusion between rule 5 (a) and rule 5 (c) hearings, the former being the defendant's initial appearance before the commissioner where he is told of his rights to counsel and preliminary examination. But " 9 commissioners affirmatively stated that a defendant should not be deprived of a preliminary hearing because the grand jury indicts." See United States v. Salliey, 360 F.2d 699, 704 (4th $\mathrm{Cir}$. 1966), where the court notes that the district judge suggested that a preliminary examination be given even though an indictment had been returned.

32 United States v. Gray, 87 F. Supp. 436, 437 (D.D.C. 1949). But see Drew v. Beard, 290 F.2d 741, 742 (D.C. Cir. 1961) (fact that defendant is at liberty on bond is no reason for denying a prompt preliminary examination).

33 See Ex parte United States, 287 U.S. 241, 250 (1932) ("It reasonably cannot be doubted that ... the finding of an indictment ... conclusively determines the existence of probable cause for the purpose of holding the accused to answer.") ; United States v. Universita, 192 F. Supp. 154, 156 (S.D.N.Y. 1961); United States v. Fitzgerald, 29 F.2d 573, 574 (E.D.Pa. 1928); United States v. Averett, 26 F.2d 676, 678 (W.D.Va. 1928) (after an indictment "what an examining magistrate thinks as to the probable guilt of the defendant is of absolutely no importance").

34 Nelson v. Sacks, 290 F.2d 604 (6th Cir.), cert. denied, 368 U.S. 921 (1961); United States v. Shields, 291 F.2d 799 (6th Cir. 1961); United States v. Pickard, 207 F.2d 472 (9th Cir. 1953) ; Gomes v. United States, 219 F. Supp. 747 (D.Conn. 1963). This was also true before the Federal Rules. United States $e x$ rel. Kassin v. Mulligan, 295 U.S. 396 (1935); United States v. Simon, 248 F. 980 (E.D.Pa. 1916) (dictum); United States v. Kilpatrick, 16 F. 765 (W.D.N.C. 1883); United States v. Fuers, 25 F. Cas. 1223 (No. 15,174) (D.C.W.D. Pa. 1871).

35 FED. R. CRIMr. P. 4(b) (1) and (2).

36 FED. R. CRIMT. P. 5 (a).

37 But see note 25 supra and accompanying text.

38 See United States v. Motte, 251 F. Supp. 601, 605 n.3 (S.D.N.Y. 1966). 
probable cause and that discovery under rule $5(\mathrm{c})$ is merely an "incidental result." 39

Nevertheless, it has been shown that discovery is indeed an important function of preliminary examinations. But only the Court of Appeals for the District of Columbia Circuit has explicitly recognized this and taken some limited steps in ordering post-indictment preliminary examinations. In Blue v. United States, ${ }^{40}$ the defendant, after conviction, claimed his indictment should have been dismissed upon the ground that his waiver of preliminary examination was given without counsel. The court of appeals stressed that the preliminary examination functions both as a means of determining probable cause and as a discovery device. ${ }^{41}$ Although affirming the conviction, the court stated that in the future a defendant could challenge the failure to conduct a preliminary examination by habeas corpus or mandamus after indictment but prior to trial. ${ }^{42}$ The court based its adoption of this procedure

$39 \mathrm{Id}$. Most courts will rarely consider and usually reject the contention that the preliminary examination is a discovery device. See, e.g., United States v. Averett, 26 F.2d 676, 679 (W.D.Va. 1928) ("If there is anywhere authority for the statement that it is a purpose of the preliminary examination to inform the defendant of the evidence relied on by the prosecution, I have not encountered it.") ; Martinez v. State, 423 P.2d 700,711 (Alaska 1967) ("[W]e do not agree that its principal function is that of providing pre-trial discovery.").

40342 F.2d 894 (D.C. Cir. 1964), cert. denied, 380 U.S. 944 (1965).

41 Id. at 899,901 .

$42 I d$. at 900 . It is questionable whether this procedure is permissible under present law. Habeas corpus does appear to be a proper remedy to review the preliminary examination, at least before an indictment has been returned. In United States ex rel. Kassin v. Mulligan, 295 U.S. 396 (1935), the Court held that a commissioner's findings in a removal proceeding may be reviewed on a writ of habeas corpus. The reasoning of the Court would also seem applicable to review of the commissioner's finding of probable cause at the preliminary examination:

The question so raised is whether petitioner is unlawfully deprived of his liberty. He was entitled to introduce evidence to prove the absence of probable cause and to have the commissioner judicially consider it. . . .

... The Circuit Court of Appeals ... declined to examine the evidence upon the ground that "our review of his (the commissioner's) decision ends as soon as we are assured that he has honestly considered all the evidence presented to him. No matter how flagrantly mistaken he may be in the result, a court will go no further." We disapprove that declaration.

Id. at 401-402. Accord, Tinsley v. Treat, 205 U.S. 20 (1907) (removal proceedings); Washington v. Clemmer, 339 F.2d 715, 716 n.2 (D.C. Cir. 1964) (habeas corpus was proper remedy at common law); United States v. Bloomgart, 24 F. Cas. 1180 (No. 14,612) (D.C.S.D.N.Y. 1868) (habeas corpus used to challenge sufficiency of evidence before magistrate at preliminary examination); In re Bates, $2 \mathrm{~F}$. Cas. 1015 (No. 1099a) (D.C.S.C. 1858). Contra, DiCesare v. Chernenko, 303 F.2d 423 (4th Cir. 1962) (habeas corpus improper save in exceptional circumstances; motion to dismiss commitment is appropriate).

But after an indictment is returned, habeas corpus does not seem to be a proper method to review the commissioner's determination of probable cause, since the defendant is now no longer "unlawfully deprived of his liberty." At this point, the defendant's remedy, denominated most often as a motion to dismiss the indictment, would appear to rest on the theory advanced in United States v. Casino, 286 F. 976 (S.D.N.Y. 1923), which involved a commissioner's denial of the relief which should have been granted under statute. Judge Learned Hand held that review of his conduct could "at any time be taken over by the court of which the commissioner is an officer," because the commissioner acts in a "ministerial" or "quasi-judicial" capacity. Id. at 980. Accord, Go-Bart Co. v. United States, 282 U.S. 344, 354 (1931) ; United States v. Florida, 165 F. Supp. 328, 331 (E.D.Ark. 1958); United States v. Zerbst, 111 
on the District of Columbia Legal Aid Act, ${ }^{43}$ which provided for the assignment of counsel to indigents at preliminary examinations in felony cases. The court reasoned that if Congress "had thought that disregard of its efforts to provide counsel in preliminary examinations . . . could be absolved by the return of an indictment, there would seem to have been little point in its taking the trouble to address itself directly to the provision of counsel in preliminary examinations in felony cases." 44 Thus the denial of a hearing should not be "swept under the rug of a grand jury indictment" nor should the availability of a remedy depend upon whether defense counsel brings habeas corpus or mandamus to compel the hearing before the United States Attorney obtains an indictment. ${ }^{45}$

The extension of Blue has been slow, ${ }^{46}$ and has not gone unchallenged by certain judges of the District of Columbia Circuit. ${ }^{47}$ However, Blue has been successfully invoked in circumstances other than uncounseled waiver of the preliminary examination. In Holmes v. United States, ${ }^{48}$ the defendant, appealing his conviction, relied on Blue to convince the court to remand for a hearing on whether his lawyer at the preliminary examination was incompetent or "failed to

F. Supp. 807, 809 (E.D.S.C. 1953) ; United States v. Berry, 4 F. 779 (D.Colo. 1880). Regardless of the remedy pursued, courts have been notably reluctant to review a commissioner's finding of probable cause. E.g., United States v. Zerbst, 111 F. Supp. at 810 ("I would refuse, however, to review the findings of the commissioner in any case except one such as this. In this case, the defendant is a county police officer ...."); Washington v. Clemmer, 339 F.2d 715, 721 (D.C. Cir. 1964) ("The course taken... opens up countless applications for the writ with subsequent appeal, leading inevitably to interminable delays in the trial of criminal cases.") (statement by Danaher, Miller and Bastian, JJ.).

The remedy will, however, make a difference for appellate review. Habeas corpus is appealable by statute, 28 U.S.C. $\$ 2253$ (1964); when the commissioner's ministerial actions are reviewed on a motion to dismiss the indictment, the district court's determination is interlocutory, i.e., denial of the motion does not terminate the criminal proceedings. Therefore, it would almost certainly not be appealable. Parenthetically, it is interesting to note that one commissioner asserted at the hearings on the Federal Magistrates Act that "there is no appeal from the magistrate's essentially administrative determination." Testimony of Robert J. O'Connor, U.S. Commissioner, District of Kansas, Hearings, supra note 6, at 204 (emphasis added).

Another difference in the denomination of the remedy is the interesting possibility that habeas corpus, being a civil action, would enable the defendant to avail himself of the discovery devices of the Federal Rules of Civil Procedure. See United States ex rel. Seals v. Wiman, 304 F.2d 53, 63-64 (5th Cir. 1962) (civil discovery devices available; question not discussed), cert. denied, 372 U.S. 915 (1963); Knowles v. Gladden, 254 F. Supp. 643 (D.Ore. 1965); cf. Chessman v. Teets, 239 F.2d 205 (9th Cir. 1956), rev'd on other grounds, 354 U.S. 156 (1957). Contra, Sullivan v. United States, 198 F. Supp. 624 (S.D.N.Y. 1961) (proceedings under 28 U.S.C. \$2255 (1964)).

43 D.C. CoDE ANn. \$2-2202 (1967).

44 Blue v. United States, 342 F.2d at 899.

45 Id. at 899-900.

46 Blue has been specifically rejected in United States v. Motte, 251 F. Supp. 601, 605 n.3 (S.D.N.Y. 1966), and, under analogous state rules, in Martinez v. State, 423 P.2d 700, 711-12 (Alaska 1967).

47 See the views of the various judges in the denial of rehearing en banc in Ross v. Sirica, 380 F.2d 557, 561-69 (D.C. Cir. 1967).

48370 F.2d 209, 211 (D.C. Cir. 1966). 
function." In Ross $v$. Sirica, ${ }^{49}$ the defendant, on a pre-trial motion, was granted a post-indictment examination at which the commissioner was ordered to grant his request to subpoena witnesses. Thus from the uncounselled waiver in Blue, the court has moved to granting a post-indictment examination in a case where the defendant was "deprived of a proper hearing" 50 because he did not have the opportunity to present evidence bearing on probable cause.

The problem with Ross, and indeed with Blue itself, is demonstrated in another District of Columbia case decided after Blue. In Crump v. Anderson, ${ }^{51}$ the defendant (unlike Mr. Blue) was not deprived of his right to counsel ${ }^{52}$-his preliminary examination was continued for a total of eleven days so that counsel could be appointed. ${ }^{53}$ During that time an indictment was returned and, on the scheduled date, the commissioner dismissed the examination. The court of appeals, in refusing to grant a post-indictment examination, treated the case as a rule 9 proceeding, ${ }^{54}$ despite the fact that Crump was arrested before indictment. ${ }^{55}$ This characterization can only be explained as based on the conception, implicit in the rules, that the preliminary examination serves only to find probable cause, and is unnecessary after an indictment has been returned. It would seem impossible to reconcile this view of the preliminary examination with that expressed in Blue ${ }^{56}$-or with the results in Holmes and Ross. As the dissenting

49380 F.2d 557 (D.C. Cir. 1967).

50 Id. at 560 .

51352 F.2d 649 (D.C. Cir. 1965).

52 This was one ground on which Crump was distinguished from Blue. Crump v. Anderson, 352 F.2d at 656 n.20.

53 Id. at 650 .

The commissioner is a judicial officer who has a "right, for good cause shown, to grant a continuance of a hearing." United States v. Gray, 87 F. Supp. 436, 438 (D.D.C. 1949). Some interesting examples of the "good cause shown" are found in Commissioners Survey, sipra note 30 , at 485 :

Reasons advanced by the government on behalf of a request for continuance in a preliminary hearing include: conflict in schedules (reported by 50 commissioners); additional time to prepare (reported by 48 commissioners); time to obtain indictment (reported by 15 commissioners); time to arrange to come to the commissioner's location from a distant U.S. Attorney's office (reported by 12 commissioners).

A number of commissioners mentioned that the government requests additional time in order to obtain additional evidence, leading to the inference that as of the time the continuance was requested, the government did not have enough evidence to establish "probable cause."

For other reasons, see id. at 485-86. The survey also showed that "[t]wo hundred eleven commissioners said that they routinely grant continuances requested by both government and the defense; 101 that they do not routinely grant such requests; 5 said that they routinely grant requests by the government only; and 7 that they routinely grant requests by the defense only." Id. at 486.

The proposed Federal Magistrates Act, S.945, 90th Cong., 1st Sess. (1967), would write into law a ten-day limitation (or twenty days if the defendant is out on bail) on holding the examination. This limit could be set aside by the district judge if indispensible to the attainment of justice.

54 As pointed out above, the difference in proceedings under rule 5 and rule 9 reinforces the conclusion that post-indictment examinations cannot be ordered consistently with the Federal Rules. See notes 34-39 sipra and accompanying text.

55 Crump v. Anderson, 352 F.2d at $650,657$.

58 See text accompanying note 41 supra. 
judge in Crump stated, "[s] ince a preliminary proceeding without the advice of counsel is ground for relief when timely raised, a fortiori, the denial of a hearing altogether is a ground for relief." 57

The problem is with Blue itself-given the context of the rules, Blue must be wrong. ${ }^{58}$ To provide indigents with counsel in preliminary examinations is not to give a mandate for ordering post-indictment examinations. It merely requires that when a preliminary examination is held, counsel must be provided. ${ }^{59}$ It may prove crucial that the defendant is represented at the preliminary examination if it takes place, aside from whether the examination be held at all. The importance of counsel at this stage is well illustrated by Nance $v$. United States, ${ }^{60}$ where the defendant, representing himself at the examination, asked a robbery victim this "near historic inquiry: "How do you know it was me, when I had a handkerchief over my face?" "61 The question was admitted at trial, obviously with damaging results. Admittedly, ordering a post-indictment hearing may be one remedy that could be fashioned where an uncounseled examination occurred. ${ }^{62}$ But this remedy would be of little help to someone in the Nance situation, where the damage has already been done; a more effective remedy in such a case would be to hold the statement inadmissible

57 Crump v. Anderson, 352 F.2d at 658.

58 It must be noted that Blice cannot be rejected because of its reliance on the District of Columbia Legal Aid Act. Rules 44 and 5(b) have since been amended, the former providing for assigned counsel to indigents "at every stage of the proceedings from his initial appearance before the commissioner or the court through appeal" and the latter providing that the commissioner must inform the defendant that counsel will be appointed if he is unable to obtain counsel. These provisions go even further than the District of Columbia act under which Blue was decided. See text accompanying note 43 sicpra.

59 There is some doubt whether there is a constitutional right to counsel in a preliminary examination in the federal system. Although in White v. Maryland, 373 U.S. 59 (1963), the Court held Maryland's preliminary examination to be a "critical stage" requiring counsel, the defendant there was called upon to plead. Rule 5 (c) specifically forbids asking for the defendant's plea. In Pointer v. Texas, 380 U.S. 400 (1965), the state's preliminary examination did not allow pleas, but the Court refused to decide whether counsel was required, stating that White was not "necessarily controlling." Id. at 402. For indications that the preliminary examination may indeed be a "critical stage," see text accompanying notes 60-61 infra. A lower court has held that the defendant does have a constitutional right to counsel at the preliminary examination. Wood v. United States, 128 F.2d 265 (D.C. Cir. 1942) (alternative ground) (Rutledge, J.). Contra, Burrall v. Johnston, 53 F. Supp. 126 (N.D.Cal. 1943), aff'd, 146 F.2d 230 (9th Cir. 1944), cert. denied, 325 U.S. 887 (1945); see 1 L. OrFIELd, CrimINAL PROCEDURe UNDER THE FEDERAI Rules 257 (1966) ("One must conclude from the cases that there is no constitutional right to counsel at the stage of the proceedings before the commissioner. ...").

60359 F.2d 273 (D.C.Cir. 1966).

61 Id. at 274.

62 That counsel may be important, not only during the examination, but also in deciding whether to waive the examination, is indicated in Commissioners Survey, supra note 30, at 479-80. This conclusion lends support to Blue, where defendant waived the examination without counsel. The survey indicates that a large percentage of urban commissioners felt that counsel and waiver were related. One commissioner responded that "[c]ounsel are not nearly so quick to waive hearing as defendant who is anxious normally to be released on bond and is not interested in hearing * * *?" Id. at 479. But regardless of the support the data may give to Blue on the waivercounsel issue, it is of no help in cases where the defendant, represented by counsel, fails to get a hearing because of continuances and an intervening indictment. 
at trial. Most other complaints would deal with the probable cause aspects and would be mooted by the indictment, which conclusively determines that probable cause exists. ${ }^{63}$ Thus Blue not only is inconsistent with the rules, but also fails to provide an adequate remedy in the type of situation where an uncounseled preliminary examination damages the defendant. It certainly affords no opportunity for expansion to cases where defects other than lack of counsel occur at the examination.

The present rules, therefore, can lead to only one conclusion: indictment moots the right to preliminary examination. But the preliminary examination, when utilized, does give some measure of discovery to defendants. ${ }^{64}$ From a policy standpoint, the question is whether the United States Attorney ought to be permitted to circumvent the preliminary examination. It must be understood that this question should not be confused with the general controversy over expansion of criminal discovery. ${ }^{65}$ Nor does the question present the choice of either expanding the preliminary hearing along the English lines or adopting the devices now used in the Federal Rules of Civil Procedure. ${ }^{66}$ Since the preliminary examination is functioning, ${ }^{67}$ evidently without the disastrous results prophesied by some opponents of greater criminal discovery, the question is merely whether this device ought to be utilized more fully until the time comes when a more accurate prediction can be made about the effects of expanded criminal discovery. If the answer is in the affirmative, and the considerations examined above ${ }^{68}$ indicate that it should be, then the proper solution is a change in the rules to make the preliminary examination mandatory. ${ }^{69}$

63 See note 33 supra and accompanying text.

64 See notes 19-27 supra and accompanying text.

65 Compare Flannery, Prosecutor's Position, Discovery in Federal Criminal Cases, 33 F.R.D. 47, 74 (1963), with Pye, The Defendant's Case for More Liberal Discovery, Discovery in Federal Criminal Cases, 33 F.R.D. 47, 82 (1963).

${ }^{6}$ See Goldstein, The State and the Accused: Balance of Advantage in Criminal Procedure, 69 YALE L. J. 1149, 1193 (1960) (rather than adopting examination modeled along English line, discovery devices similar to those in the Federal Rules of Civil Procedure should be utilized since American courts are more accustomed to applying them); S. REP. No. 371 , supra note 18, at 34 ("While your committee agrees that criminal discovery in the Federal courts should be more liberal than it has been in the past ... your committee is of the opinion that the problem of discovery should be treated separately from that of the preliminary hearing.").

67 For example, in Pennsylvania a defendant must receive a preliminary examination before his case can be submitted to the grand jury for indictment. See Commonwealth v. O'Brien, $181 \mathrm{~Pa}$. Super. 382, 393 (1956), appeal dismissed, $389 \mathrm{~Pa}$. 109 , 132 A.2d 185 (1957). Arlen Specter, District Attorney of Philadelphia, states that "[i] $n$ the interests of justice ... it is my view that a preliminary hearing is highly desirable." And this despite his feeling that "[t]he discovery gained by the defendant at the preliminary examination sometimes has an adverse effect on the administration of criminal justice because the defendant is able to learn a great deal about the prosecution's case without any reciprocity on discovery." Letter from Arlen Specter, March 26, 1968, on file at the University of Pennsylvania Lav Review. See note 24 supra. But cf. note 30 supra.

68 See notes 19-27 supra and accompanying text.

69 The proposed Federal Magistrates Act, S. 945, 90th Cong., 1st Sess. (1967), would, on the contrary, write the standard mootness holding into statute. See note $\mathbf{5 3}$ supra. 


\section{Proposed Changes in the Federal Rules}

One way to make the preliminary examination mandatory is to amend rules 5 and $9^{70}$ of the Federal Rules of Criminal Procedure. Rule $5^{71}$ might be amended as follows (new matter is shown in italics):

\section{(c) Preliminary Examination}

(1) Procedure. All defendants shall be entitled to a preliminary examination, regardless of whether an indictment has been returned. The defendant shall not be called upon to plead. If the defendant waives preliminary examination, the commissioner shall forthwith hold him to answer in the district court. If the defendant does not waive examination, the commissioner shall hear the evidence within a reasonable time; but when the defendant is brought before the commissioner before an indictment for the offense has been returned, the commissioner shall hear the evidence no later than the day when the attorney for the government begins presenting the matter to the grand jury. In no event shall a copy of an indictment or information be admissible into evidence at the examination. A court stenographer shall transcribe the proceedings and the defendant may request a copy of the record made, such copy to be given to an indigent defendant at no expense to him. ${ }^{72}$ The defendant may cross-examine wit-

70 Minor changes would also have to be made in FED. R. CRIM. P. 40(a) and 40 (b) (3), which maintain the distinction between defendants arrested before and after indictment.

${ }_{71}$ FED. R. CRIM. P. 5 concerns defendants arrested before indictment; FED. R. CRIM. P. 9 concerns defendants arrested after indictment.

72 Professor Moore writes that "[a]t present, a defendant has no right to have a stenographer present at the hearing, unless he can afford to hire his own. This situation is certainly discriminatory. Use of the preliminary hearing to lay the groundwork for impeachment of government witnesses at the trial does not amount to much if no record of the hearing is available." $8 \mathrm{~J}$. MOORE, FEDERAL PRACTICE $\int 5.04$ [4], at 5-34 (2d ed. 1967). But cf. 28 U.S.C. \$753(b) (1964) (judge may request court reporter to transcribe parts of a proceeding); MANUAL FOR UNITED STATES CoMinissioners 10 (rev. ed. 1948) (official court reporters may be secured by commissioner, with consent of the judge, unless they are actually engaged in attendance upon a session of court; record to be made without charge, but transcript ordered by defendant must be paid for).

In Washington v. Clemmer, 339 F.2d 715 (D.C. Cir. 1964), the court ordered that a stenographer be provided at a preliminary examination without cost to an indigent defendant, stating that " $[t]$ o deny this opportunity to an indigent defendant would be to permit invidious discrimination based on wealth." Id. at 718. They further noted that in the absence of a transcript, which is not required under the present rule, it is difficult if not impossible to review the commissioner's finding of probable cause, and that a transcript "perpetuates the fresh memory of witnesses, making it available in case of subsequent death, disability, or flight, and allowing impeachment or refreshing of recollections at trial." Id. at 717.

Title III of the proposed Federal Magistrates Act, S. 945, 90th Cong., 1st Sess. (1967), provides that the proceedings be taken down by a court reporter or "suitable sound recording equipment" and that a copy "be made available at the expense of the United States to a person who makes affidavit that he is unable to pay or give security therefor, and the expense- of such copy shall be paid by the Director of the Administrative Office of the United States Courts." Title III of the 1966 proposal, S. 3475 , 89th Cong., $2 d$ Sess., provided merely that a copy "shall be made available to an indigent defendant at no expense to him." 
nesses against him and may introduce evidence in his own behalf. If from the evidence it appears to the commissioner that there is probable cause to believe that an offense has been committed and that the defendant has committed it, the commissioner shall forthwith hold him to answer in the district court; otherwise the commissioner shall discharge him. The commissioner shall admit the defendant to bail as provided in these rules. After concluding the proceeding the commissioner shall transmit forthwith to the clerk of the district court all papers in the proceeding and any bail taken by him.

(2) Motion for Relief. Should the commissioner fail to comply with the provisions of subdivision (1), or should he erroneously find probable cause to hold the defendant, the district court shall, upon motion of the defendant before trial, order the commissioner to hold an examination; or, if an examination has been held, the district court shall determine whether the evidence presented reasonably supports the commissioner's finding of probable cause. Should the district court find that the commissioner's determination cannot be so supported, he shall discharge the defendant, and if an indictment or information has been returned, he shall order it dismissed.

Rule 9 might be amended by adding the following new sections: (d) Procedure When Defendant Is Brought Before the Court. If the defendant has not received a preliminary examination, the district court shall order a commissioner to conduct one, as provided in Rule 5(c)(1). If a commissioner had previously conducted a preliminary examination at which he discharged the defendant, and the district court determines that the evidence presented at the preliminary examination reasonably supports the commissioner's finding of no probable cause, he shall discharge the defendant and order the indictment or information dismissed; but if the district court determines that the commissioner's finding cannot be so supported, he shall hold the defendant for trial and admit him to bail as provided in these rules.

(e) Motion for Further Relief. If a commissioner has discharged the defendant, after a preliminary examination on an offense for which an indictment is still outstanding, and the attorney for the government has failed to request a warrant or summons as provided in section $(a),{ }^{73}$ and if a commissioner

73 FED. R. CRIM. P. 9(a) describes the procedure for issuance of a warrant or summons upon indictment or information. 
has not held a subsequent examination at which probable cause was found, the defendant, at any time after thirty days from the date he was discharged by the commissioner, may make a motion to the district court to dismiss the indictment. If the district court determines that the evidence presented at the preliminary examination reasonably supports the commissioner's finding of no probable cause, he shall order the indictment dismissed, unless contrary to the interests of justice.

A brief description of how the suggested provisions should function may be helpful. The United States Attorney would initially have the choice of arresting the defendant under a rule 4 warrant, issued upon a complaint, or under a rule 9 warrant, issued upon an indictment or information. Both procedures would present the defendant to the commissioner for a preliminary examination ${ }^{74}$ to determine whether probable cause exists. If he finds no probable cause, he would discharge the defendant. If he finds probable cause, he would hold the defendant for trial; the defendant would then have the choice of accepting the commissioner's determination or making a motion, before trial, ${ }^{75}$ for

74 Defendants arrested before or after indictment would be entitled to an examination "within a reasonable time." Defendants arrested before indictment, however, would receive their preliminary examinations no later than the day the United States Attorney goes to the grand jury. Under 5(c) (2) all defendants would be entitied to make a "demand" motion to get a preliminary examination if the commissioner has not held one within the prescribed period.

It is hoped that this entire procedure will give some content to the "reasonable time" provision in the present rule, thus taking away from the magistrate his almost unlimited discretion to grant postponements. See discussion of the proposed Federal Magistrates Act, note 53 supra. While the United States Attorney may quite legitimately ask for delays in the preliminary examination, for example to enable him to assemble his witnesses, when he is ready to present the evidence to the grand jury there appears to be no reason why he would not be just as well prepared for the preliminary examination. To give an extreme example of granting postponements, in United States v. Delman, 253 F. Supp. 383 (S.D.N.Y. 1966), there were nearly fifty postponements of the preliminary examination extending over four years before an indictment was returned. Defense counsel there, however, were partly responsible, since they never appeared after the initial postponement. In United States v. Cowan, 37 F.R.D. 215 (S.D.N.Y. 1965), the examination was postponed five times, over an almost three-month period, without either defense counsel or the commissioner being asked-the Assistant United States Attorney merely marked the commissioner's calendar the afternoon before the examination with whatever date he thought appropriate. See Drew v. Beard, 290 F.2d 741 (D.C. Cir. 1961) (defendants alleged that commissioner, stating that he would not allow examination to be used as a means of discovery, postponed examination for the purpose of awaiting indictment); James $v$. Lawrence, 176 F.2d 18 (D.C. Cir. 1949) (month delay, the grand jury not having yet acted, is not unreasonable; when true bili is returned there will be no need for examination). Many state statutes place a time limit on granting continuances. See ALI Code of CrmirinaI Procedure \$\$ 39-60 (1931).

In addition, holding the preliminary examination on the same day that the United States Attorney goes to the grand jury would be more efficient, at least from the standpoint of witness inconvenience. See United States ex rel. Wheeler v. Flood, 269 F. Supp. 194, 198-99 (E.D.N.Y. 1967).

75 The proposed rule contemplates a pre-trial motion; absent extraordinary circumstances resulting in unusual prejudice to the defendant, a deficient preliminary examination would not justify reversal of a conviction on appeal. The court in Blue v. United States, 342 F.2d 894, 900-01 (D.C. Cir. 1964), cert. denied, 380 U.S. 944 (1965), adopted this procedure and gave rather convincing reasons: 
review by the district judge under rule 5 (c) (2). If the district judge finds that the evidence presented at the preliminary examination reasonably supports the finding of probable cause, he would hold the defendant for trial; ${ }^{76}$ if he finds that the evidence does not support the commissioner's determination, he would discharge the defendant. Any indictment returned before the district judge's discharge of the defendant would be dismissed.

Faced with a finding of no probable cause by a commissioner, the United States attorney may choose to drop the prosecution or to rearrest the defendant, possibly after gathering more evidence. If he rearrests under rule 4 , the above procedure would again operate. If he chooses to use rule 9 , for which he would need an indictment or information, the defendant would be brought before the district court, which would then have to review the commissioner's finding of no probable cause to determine whether it was reasonably supported by the evidence presented at the preliminary examination. If it was, the defendant would be discharged and the indictment or information would be dismissed; if it was not-i.e., probable cause was shown at the examination-the defendant would be held for trial. For defendants discharged at this point, the process could conceivably continue until there is a finding of probable cause by a commissioner and either a failure by the defendant to appeal or an affirmance by the district court of the commissioner's finding of probable cause.

The defendant would also have several options open to him. He may decide not to appeal the commissioner's determination of probable cause, or he may decide to waive the examination. He may also "demand" review of the commissioner's determination of no probable cause at any time more than thirty days after the examination in order to get an outstanding indictment dismissed. Under the rule 9(e) procedure suggested, the defendant would bring himself into court instead of waiting for the United States Attorney to act, thus avoiding to some extent the unpleasant pressure of suspended proceedings.

All the procedures described above appear to be necessary to effectuate the main purpose of the proposed rules, which is to give all defendants preliminary examinations regardless of when an indictment is returned. The major difficulty this raises is the occurrence of post-

With counsel appearing either at the preliminary hearing stage itself, or, at the latest, before arraignment upon the indictment, there is normally adequate time before trial to file the necessary petitions if they are called for. Naturally, the attorney will be entitled, upon consultation with his client, to decide that a minor flaw is not worth challenging, or that, as a tactical matter, it is to the defendant's advantage to forego the point. Thus, unless some reason is shown why counsel could not have discovered and challenged the defect before trial, it will generally be assumed that any objections to the preliminary proceedings were considered and waived, and no post-conviction remedies will be available.

76 If the district judge agrees with the commissioner's determination of probable cause, the defendant may have a chance for appellate review by habeas corpus, at least before an indictment has been returned. See note 42 supra. 
indictment examinations-there must be some way to insure that they will be meaningful. If they were ordered under present law, it is possible that the United States Attorney would not present sufficient evidence at the preliminary examination, knowing that he could still go to trial on the indictment, regardless of the commissioner's ruling. ${ }^{77}$ A sanction is needed to force the United States Attorney to present enough evidence to show probable cause and to attach important consequences to the commissioner's finding. The sanction chosen is dismissal of the indictment. ${ }^{78}$ In certain cases, however, this would

77 It is also possible that a commissioner, knowing an indictment has been returned, would not weigh the evidence with much deliberation. Making the indictment inadmissible at the preliminary examination, as the proposed rule 5 (c)(1) would, ought to avoid this type of prejudice.

78 The proposed rules also provide that an information, like an indictment, shall be dismissed upon the court's finding that probable cause was wanting. It is doubtful that such a result could obtain under the present rules. Although no cases could be found where a court held that preliminary examination was mooted when, after arrest, the United States Attorney decided to proceed by information under FED. R. CRIM. P. T(a), such a result would seem to be required by the present rules. FED. R. CRIMr. P. 9 (b) (1) and 9 (b) (2) provide that a defendant arrested on a warrant or summons issued upon an information must be brought before the court. As in the case of a defendant arrested after an indictment, therefore, the defendant arrested after an information is not entitled to a preliminary examination. Cf. United States v. Pickard, 207 F.2d 472 (9th Cir. 1953). Therefore, an intervening information, like an intervening indictment, should moot the preliminary examination; see notes 31-39 supra and accompanying text. One pre-rules case denied a motion to quash an intervening indictment. United States v. Achen, 267 F. 595 (E.D.N.Y. 1920). Before the rules, it appears that

[d] espite some practice and statements to the contrary, it may be accepted as settled, that leave [to file an information] must be obtained; and that before granting leave, the court must, in some way, satisfy itself that there is probable cause for the prosecution. ... The United States Attorney ['s] ... official oath may be accepted as sufficient to give verity to the allegations of the information.

Albrecht v. United States, 273 U.S. 1, 5-6 (1927) (Brandeis, J.). The result, of course, is that such a defendant would get no preliminary examination. See United States v. Simon, 248 F. 980 (E.D. Pa. 1916). Nevertheless, there is some indication of a practice of granting an examination in such circumstances:

Whether the information presents a proper case for granting leave . . to file, is a question for the exercise of a sound discretion by the Court. Generally, in this circuit ... it has been required that the party charged shall be examined and held to answer by some committing magistrate, or else that evidence showing probable cause should be made to appear in some proper form before granting leave.

United States v. Reilley, 20 F. 46 (C.C. Nev. 1884).

Under the rules, however, an information may be filed without leave of court, FED. R. CRIM. P. 7(a), but a warrant for a defendant named in the information must be "supported by oath" before the court may issue it, thus satisfying Albrecht. FED. R. CRIM. P. 9(a). It is nevertheless difficult to see how an information supported by oath supplies much greater assurance of probable cause than does a complaint "made upon oath." FED. R. CRRM. P. 3. The complaint sets in motion proceedings under rule 5 ; the information does not. But should we be less worried about defendants being frivolously prosecuted-or about their obtaining a measure of discovery-simply because they are not liable to imprisonment for more than one year? Under the proposed rule 5 (c), this loophole would be closed, although admittedly dismissal of the information, as provided in subdivision (2), would be considerably less troublesome to the United States Attorney than dismissal of an indictment, and his incentive to assure that the preliminary examination was adequate correspondingly less. The process of swearing to an information would seem considerably simpler than preparation and presentation of a case to a grand jury. On the other hand, we are speaking here of misdemeanors, where the pressure on the prosecutor for convictions is considerably less. This fact, along with the prosecutor's sense of honor in swearing to the information, should alleviate most of the problems. 
effectively allow a commissioner's finding of no probable cause to overrule the grand jury's finding of probable cause. ${ }^{79}$ Nevertheless, the procedure adopted for this "overruling," in addition to being the only way to give defendants arrested after indictment the same chance for discovery as those arrested before indictment, also gives greater assurance that all defendants are being properly held for trial, and sufficiently checks an inaccurate determination by a commissioner.

The sanction of dismissing an indictment may seem harsh, but it is difficult to conceive of a sanction which would be less harsh and yet be effective. Without an indictment, and with the defendant released from custody, the United States Attorney is back where he started. He must rearrest the defendant, if he can, ${ }^{80}$ and go through the time and effort of re-indicting. This certainly should compel the United States Attorney to present an adequate case at the preliminary examination. The alternative-leaving to his discretion whether to continue prosecution after a post-indictment finding of no probable cause-does not appear to be an effective way to insure meaningful preliminary examinations, particularly if he is intent on avoiding discovery. ${ }^{81}$

The situation may arise where, at a post-indictment examination, the United States Attorney presents all his evidence and the commissioner rules that there is no probable cause. It has already been noted that the grand jury may not be the best vehicle for determining probable cause, particularly in light of its ex parte nature; ${ }^{82}$ if the United States Attorney cannot produce enough evidence of probable cause in open court, it is difficult to understand why he ought to be allowed to go to trial, regardless of what the grand jury has done.

Nevertheless, the grand jury has the historical preference in determining probable cause. The proposed rules attempt to resolve the conflict between this preference and the need for a meaningful postindictment examination by giving the district judge sole power to dismiss the indictment on review of the commissioner's findings. ${ }^{83}$

79 The ultimate decision, however, would be that of the district court. See text accompanying note 83 infra.

80 The defendant may have left the jurisdiction, or the statute of limitations may have reared its fearsome head.

81 See text accompanying note 1 supra. The court in Blue v. United States, 342 F.2d 894 (D.C. Cir. 1964), cert. denied, 380 U.S. 944 (1965), was faced with this problem, but rejected the remedy of dismissing the indictment. The court's reasoning does not seem compelling: "Wiping the slate clean is always a tidily appealing solution, but not seem compelling: "Wiping the slate clean is always a tidily appealing solution, but
we are not convinced that it is necessary to go so far...." Id. at 900 . It noted that a finding of no probable cause "would not affect the indictment, although the Commissioner's action would presumably cause the prosecutor to review the indictment again with care." Id. at 900 n.7 (emphasis added).

82 See note 25 supra and accompanying text.

83 The standard suggested for the district court's post-indictment review of a finding of no probable cause-whether such a finding was reasonable in light of the evidence presented at the hearing-is obviously not the only possibility. The other likely choice-whether it would have been reasonable to have fonth probable causewould, however, almost certainly prove unworkable. In all but the very scantest of 
Allowing an experienced trier of fact to resolve this conflict seems to be a functional solution; he would, at trial, be required to make a similar determination upon defendant's motion to dismiss at the close of the prosecution's case. The standard for review would be in keeping with the fact that the United States Attorney need only present enough evidence to show probable cause. In assessing this, the district court would be helped by the provision that a record must be made of the proceedings at the preliminary examination. Further, in cases where the commissioner has found probable cause, the judge would be able to tell, for example, whether the commissioner allowed cross-examination, whether a copy of the indictment was introduced at the hearing, and whether the defendant was represented by counsel. Failure to follow the provisions of $5(\mathrm{c})(1)$ would militate strongly towards, if not compel, a reversal of the commissioner's finding of probable cause. Thus, by reviewing the commissioner's actions, the district court would be able not only to assure the defendant's opportunity for discovery, but also to determine whether the defendant ought to stand trial.

\section{CONCLUSION}

Implementation of the changes suggested in this Comment would not radically alter the nature of the preliminary examination. The preliminary examination has evolved from a prosecutorial tool into a protective device for the defendant, and the proposed rules are designed to strengthen this feature. They would insure that all defendants accused of federal crimes have the opportunity to come before a judicial officer shortly after arrest. Moreover, they would provide a degree of discovery to those who desire it, lending integrity to the fact-finding process and possibly providing a means for gathering empirical data about the effects of criminal discovery on the processes involved. This information would be helpful in evaluating the desirability of expanding discovery in the criminal law context. Finally, the proposed rules would insure that the choice of whether a preliminary examination is held is that of the defendant, and not, as under present law, that of the prosecutor. It is hoped that these proposed rules would have beneficial effects on the administration of justice, far outweighing the cost in time and dollars which their adoption would entail.

preliminary examinations it would be possible to find probable cause; but the commissioner will have had the benefit of seeing and hearing the witnesses, and this second standard would totally deny the value of his evaluation of witnesses' credibility. Such review of post-indictment examinations would almost invariably result in a reversal of any finding of no probable cause. Not only would this substantially diminish the compulsion on the United States Attorney to present an adequate case, but frequent reversals would also in all probability lead the magistrates into a dangerously low standard of probable cause in all cases. 